DOI 10.15290/cnisk.2016.01.01.05

\author{
DR GRAŻYNA KĘDZIERSKA
}

Niepaństwowa Wyższa Szkoła Pedagogiczna w Białymstoku

\title{
Opinia biegłego \\ w słynnych procesach przeciwko kobietom
}

\section{Streszczenie}

Sformułowanie „wskazań wiedzy”, zawarte w treści procesowej zasady swobodnej oceny dowodów, odnosi się do wykorzystania przez organ procesowy osiągnięć nauki w postępowaniu karnym. Kluczowa jest tutaj opinia biegłego, oparta na badaniach, zgodnych $z$ aktualnym stanem nauki. Niezależnie jednak od wyniku badań prezentowanego w opinii, nigdy nie jest ona wiążąca dla sądu. Jakie więc jest znaczenie opinii biegłego dla rozstrzygnięcia istotnych watpliwości występujących w danej sprawie? Opinia biegłego zawsze miała znaczenie adekwatne do stanu nauki w danym okresie historycznym. Wraz z rozwojem nauki rosły możliwości badawcze biegłego, ustalanie okoliczności zdarzenia pozwalało rozstrzygać więcej wątpliwości. $Z$ perspektywy przestępczości kobiet w słynnych procesach, opinie biegłych czasem nie potrafiły rozstrzygnać watpliwości i dawały uniewinnienie oskarżonym, bywały mylne i dopiero zbieg okoliczności decydował o ustaleniu sprawcy, prowadziły do obarczenia wina jednej osoby i uniewinnienia drugiej, zdarzało się, że nie były brane pod uwagę, co skutkowało surowym wyrokiem, najczęściej jednak dawały możliwość wymierzenia kary.

Słowa kluczowe: ekspertyza - historia kryminalistyki • opinia biegłego • przestępczość kobiet • zasada swobodnej oceny dowodów 


\title{
THE EXPERT WITNESS'S OPINION IN WELL-KNOWN TRIALS AGAINST WOMEN
}

\begin{abstract}
The term "indications of knowledge" used in the content of the procedural principle of free appraisal of evidence refers to the judicial body using scientific developments in the area of criminal proceedings. The expert's opinion, based on the current state of knowledge, is in such cases of utmost importance. However, whatever the expert's opinion evidence, it will not be bound by the courts. So how important are the opinions of experts in settling the doubts in a criminal case? As was shown by the analysis of several well-known trials against women, the research capacity of the expert witness always corresponded to the state of science in a relevant historical period. Unfortunately, sometimes the expert witness's opinion was not able to clear up doubts and resulted in finding a defendant not guilty. Occasionally, it was erroneous and the perpetrator was identified only as a result of coincidence. In some cases the opinion led to acquitting one person and finding another one guilty, or the opinion was not taken into account by the court at all. Nevertheless, in most cases scientific findings of the expert witness presented in an opinion dispelled the doubts of the court which significantly influenced sentencing.
\end{abstract}

Keywords: history of criminology • expert witness's opinion • crime of women $\bullet$ the principle of free appraisal of evidence - scientific developments

Społecznie ważne, ogólne dyrektywy dotyczące najbardziej istotnych kwestii z zakresu procesu karnego zostały uregulowane w zasadach procesowych ${ }^{1}$. Za niezwykle istotna wśród tych kil-

\footnotetext{
1 A. Murzynowski, Istota i zasady procesu karnego, Warszawa 1994, s. 110. Cechy zasady: zasada musi posiadać węzłowe znaczenie dla określenia modelu procesu; zasada powinna zawierać określona treść ideologiczną i społeczna, wskazując cele i wartości, jakie należy osiagnąc w danej społeczności; zasada powinna dotyczyć bezpośrednio procesu, niezależnie od obowiazywania w innych gałęziach prawa (zasadami procesowymi nie sa: zasada humanizmu, demokratyzmu jako uniwersalne); zasada powinna być sformułowana w sposób dyrektywny, który wyraża pewną prawidłowość, rozwiązanie organizacyjne lub zachowanie się. Podział zasad:

- naczelna zasada: zasada prawdy,
} 
kunastu dyrektyw uznaje się zasadę swobodnej oceny dowodów, która stanowi, że organ procesowy ${ }^{2} \mathrm{w}$ ocenie dowodów kieruje się swoim przekonaniem nieskrępowanym ustawowymi regułami oceny, ukształtowanym pod wpływem wskazań wiedzy, doświadczenia życiowego i zasad logicznego rozumowania. Kluczowe, dla poniższych rozważań $\mathrm{w}$ treści tej zasady jest sformułowanie wskazań wiedzy, które odnosi się do wykorzystania przez organ procesowy osiagnięć nauki w przeprowadzaniu dowodów. Zasada swobodnej oceny dowodów jest w prawie procesowym bezwarunkowo statuowana i wskazuje na brak możliwości wartościowania jakichkolwiek dowodów. Opinia biegłego oparta na badaniach zgodnych $z$ aktualnym stanem nauki nigdy nie jest jednak wiażąca dla sądu, jest tylko środkiem dowodowym i podlega swobodnej ocenie, tak jak inne środki dowodowe.

Opinia jest końcowym wynikiem badań podejmowanych przez biegłego w ramach czynności procesowej, jaka jest ekspertyza ${ }^{3}$. Biegły to osoba posiadająca wiadomości specjalne, wezwana do zbadania i wyjaśnienia okoliczności istotnych dla rozstrzygnięcia sprawy. Wiadomości specjalne, które stanowią atrybut biegłego, są wiedza, która w określonym czasie przekracza zasób informacji przeciętnie wykształconego, dorosłego człowieka w dziedzinie na-

- zasady materialno-procesowe: zasada wychowawczego oddziaływania wymiaru sprawiedliwości, zasada legalizmu, zasada ścigania $z$ urzędu,

- zasady dotyczace formy procesu: zasada skargowości, zasada kontradyktoryjności, zasada publiczności, zasada instancyjności,

- zasady dotyczace stanowiska sądu: zasada niezawisłości sędziowskiej, zasada udziału czynnika społecznego, zasada uczciwego procesu,

- zasady dotyczące sytuacji prawnej oskarżonego: zasada domniemania niewinności, zasada prawa do obrony,

- zasady dotyczace postępowania dowodowego: zasada swobodnej oceny dowodów, zasada bezpośredniości.

2 Organ procesowy jest uczestnikiem postępowania karnego. W zależności od etapu postępowania karnego organem jest np. prokurator, Policja, Straż Graniczna lub sad.

${ }^{3}$ Ekspertyza jest to zespół czynności badawczych wymagających wiadomości specjalnych i dlatego wykonywanych na zlecenie organu procesowego, zakończonych opinia mogąca mieć charakter dowodu w procesie. Definicja ta została sformułowana przez Profesora Tadeusza Hanauska, kryminalistyka i kryminologa Uniwersytetu Jagiellońskiego. Szerzej na temat badań w ramach ekspertyzy, biegłego i opinii: W. Kędzierski, Ekspertyza. Biegli [w:] Kryminalistyka. Wybrane zagadnienia techniki, red. G. Kędzierska i W. Kędzierski, Szczytno 2011, s. 450 i n. 
uki, techniki, sztuki lub rzemiosła, przy czym wiedza ta obejmuje tak teorię, jak i umiejętności praktyczne. Istota każdej ekspertyzy są czynności badawcze opierające się na wiedzy z zakresu określonej dyscypliny naukowej. Według kryterium, które stanowi rodzaj wiedzy wykorzystywanej podczas czynności badawczych, klasycznie ekspertyzy dzieli się na kryminalistyczne (a wśród nich sa daktyloskopijne, mechanoskopijne, pisma, traseologiczne, broni) oraz inne, takie jak: biologiczne, chemiczne, toksykologiczne, medyczne, informatyczne.

Opinia jest twierdzeniem formułowanym przez biegłego na podstawie wniosków osiagniętych $z$ wyników badań. Sąd nigdy nie jest zwiazany twierdzeniem biegłego i zawsze dokonuje swobodnej oceny każdej opinii. Swobodnej - nie oznacza jednak dowolnej, co podkreśla się tak w doktrynie, jak i w orzecznictwie. Zdarza się, że nawet opinia $z$ badań daktyloskopijnych ${ }^{4}$ nie zostaje uznana przez sad za dowód $\mathrm{w}$ sprawie. Nie umniejsza to w żadnym razie roli badań i opinii biegłego w ustalaniu okoliczności istotnych dla rozstrzygnięcia sprawy.

Autorzy literatury faktu ${ }^{5}$ oraz badacze dosyć chętnie zajmuja się przestępczościa kobiet, wyraźnie faworyzując przestępstwo zabójstwa dokonywane przez kobiety. Zdarzenia tego typu maja znaczny stopień sensacyjności właśnie $z$ powodu płci sprawcy. Od wieków zabójstwo, w którym oskarżano kobietę budziło żywe zainteresowanie tak specjalistów, jak i szerokich rzesz społeczeństwa. W wielu takich przypadkach konieczność ustalenia zgodnego $z$ prawda przebiegu zdarzenia była motorem rozwoju wiedzy kryminalistycznej i nie tylko. Zważywszy poczynione na wstępie uwagi, w artykule podjęto próbę odpowiedzi na pytanie: Jakie znaczenie ma opinia biegłego $w$ ustalaniu okoliczności istotnych

\footnotetext{
4 Daktyloskopia jest metoda identyfikacji człowieka na podstawie śladów linii papilarnych palców rak. Jest to metoda najlepiej zbadana a jej ustalenia nie budza wattpliwości. Identyfikacja daktyloskopijna opiera się na trzech cechach linii papilarnych: niezmienności, nieusuwalności i indywidualności.

5 Do tej grupy należy chyba zaliczyć książki pisane na podstawie wywiadów, charakteryzujące się dużą społeczną uwaga i poczytnością, jak K. Bonda, B. Lach, Zbrodnia niedoskonała, Chorzów 2009, ss. 247 lub K. Bonda, Polskie morderczynie, Warszawa 2008, ss. 304.
} 
dla rozstrzygnięcia sprawy $w$ stynnych procesach przeciwko kobietom?

Materiał do analizy stanowiły opisy przypadków uzyskane $z$ literatury oraz ogólnie dostępnego źródła informacji - Internetu. Wybrano siedem przypadków, w których o popełnienie zabójstwa oskarżano kobietę. Rozstrzygnięcie wątpliwości pojawiających się $\mathrm{w}$ trakcie postępowania karnego wymagało, aby organy procesowe skorzystały $z$ wiedzy biegłych różnych specjalności. Przypadki obejmuja dosyć duży zakres czasowy, a niektóre pokazuja rozwój badań kryminalistycznych, $z$ zakresu medycyny sądowej oraz toksykologii, stymulowanych potrzebami praktyki.

Przestępczość kobiet była i jest silnie związana $z$ rola, jaka kobiety pełniły i pełnia w społeczeństwie. Większość kobiecych przestępstw to zdarzenia o małej szkodliwości społecznej, ale kobiety dopuszczały się $\mathrm{w}$ przeszłości i dzisiaj także zabójstw, a właśnie te przypadki zapadają w pamięć i zapisuja się na kartach niechlubnej historii kobiecych zbrodni. Sa to również sprawy, w których najczęściej organy ścigania i wymiaru sprawiedliwości zwracaja się o pomoc do biegłych. W przeszłości odbyło się niemało widowiskowych procesów, w których na ławie oskarżonych zasiadały kobiety. Orzeczenia sadów w tych procesach w dużym stopniu były uzależnione od opinii biegłych.

Dzisiaj opinia biegłego potrafi wyjaśnić wiele wątpliwości i zrozumieć okoliczności przestępstwa, jednak w całkiem nieodległych czasach zdarzało się, że nie była ona w stanie pokonać zastrzeżeń organu wymiaru sprawiedliwości. Potrzebę obiektywnej pomocy prokuratorom i sędziom $\mathrm{w}$ ustalaniu okoliczności istotnych dla rozstrzygnięcia sprawy widziano już bardzo dawno, ale stan nauki był poważną blokada jakichkolwiek racjonalnych działań $\mathrm{w}$ tej dziedzinie.

Ilustracja takiej sytuacji, trwającej kilka stuleci, sa procesy czarownic. W XV wieku, moca swojego autorytetu, Kościół Katolicki potwierdził istnienie czarownic, a w 1487 r. ukazało się dzieło dwóch dominikanów Hainricha Kraemera i Jacoba Sprengera pt. Młot na czarownice, w którym opisano cechy czarownicy, ro- 
dzaje uprawianych czarów i sposoby zwalczania czarodziejstwa6. Żeby jednak doszło do skazania kobiety za uprawianie czarów, konieczna była jej identyfikacja jako czarownicy. Dokonywano tego przez szczególny rodzaj badania. Otóż jeżeli na ciele kobiety ujawniono znamię, wbijano w nie szpilkę. Płynąca po takim zabiegu krew miała wskazywać, że znamię jest punktem karmienia diabła, co oczywiście było równoznaczne ze stwierdzeniem, że kobieta była czarownica 7 . Tak przedstawiał się ówczesny rodzaj badań identyfikacyjnych. Procesy o czary - chociaż z punktu widzenia obowiązującego wówczas prawa nie można im nic zarzucić sa przykładem niesłusznego sądzenia kobiet i skazywania ich za czyny, których w rzeczywistości nie popełniły. Kobiety w tych procesach były ofiarami systemów politycznych, wierzeń i zabobonów ${ }^{8}$, a prymitywne badanie nazywane dowodem reprezentowało ówczesną naukę.

Przez wiele wieków trucizny były niewykrywalne, nie było metod ich oznaczania w płynach ustrojowych i tkankach ludzkich. Niewątpliwie trucizną może być każda substancja. Wszystko zależy od ilości, sposobu podania i wrażliwości organizmu, który substancje przyjmuje. Popularne były trucizny roślinne, ale to arszenik ${ }^{9}$ był uważany za substancję powszechnie stosowaną właśnie

6 S. Wrzesiński, Potępieńcy średniowiecznej Europy, Kraków 2007, s. 65; D. Alexander, Czarownice, wróżbici, szamani. Podróż przez świat mitów i magii, Warszawa 2008, s. 59.

7 Dwa inne warunki uznania za czarownice polegały na ustaleniu, czy po kłótni z kobieta zdarzały się nieszczęśliwe wypadki i czy widziano, jak postać kobiety czyni szkodę. Ostatni $z$ wymienionych warunków nazywano dowodem widmowym.

$8 \mathrm{Na}$ przykład latem 1775 r. w Doruchowie, wsi położonej pod Kępnem w powiecie ostrzeszowskim oskarżono o czary czternaście wiejskich kobiet, zasązono je na spalenie po pławieniu i torturach a następnie spalono. Dramat rozpętała żona dziedzica Doruchowa, która żaliła się na prześladowania czarownic, twierdząc, że wszystkie jej dolegliwości pochodzą od uroków. S. Szenic, $P i-$ taval wielkopolski, Poznań 1977, s. 9 i n.

9 Arszenik nazywano trucizną wszech czasów. Jako pierwszy wyodrębnił go w VIII wieku arabski alchemik Geber. Był nazywany „trucizną królewską, "proszkiem dziedziczenia”, bo jako biały, bezsmakowy proszek łatwo było go domieszać do potraw i napoi. Zaczyna działać po kilku godzinach od spożycia, wywołując objawy jak przy zatruciu pokarmowym. Toksykologia u zarania swoich dziejów za podstawowy problem uznała opracowanie metod wykrywania tej trucizny w tkankach zwłok. Znaczny udział w tych poszukiwaniach maja polscy badacze. J. Widacki, Stulecie polskich detektywów, Kraków 1992, s. 104, 105. 
przez kobiety do pozbawiania życia niewygodnych osób. W Rzymie tylko w roku 184 p.n.e. za trucicielstwo skazano prawie dwa tysiace kobiet ${ }^{10}$. Najsłynniejsza trucicielka była wtedy Lukusta, która działała w sferach rzymskiej arystokracji11.

W roku 1850 w Belgii popełniono zbrodnię, której wyjaśnienie wymagało zaangażowania biegłego chemika. Dwoje sprawców, hrabia Hippolit Visart de Bocarmé i jego żona Lidia12, dokonało zabójstwa Gustawa Fougnies. Zbrodnię popełniono w zamku Bitremont. Gustaw był bratem Lidii, a motywem były pieniądze. Do zabójstwa użyto nikotynę - alkaloid roślinny uważany wtedy za niewykrywalny. Aby zatrzeć ślady trucizny, zabójcy wlewali w usta Gustawa i polewali jego ciało octem winnym. Sekcja zwłok wykazała śmierć gwałtowną, wskutek wypicia żrącej substancji jednak nie było wiadomo jakiej. Belgijski chemik Jean Servais Stas (1813-1891) przeprowadzał badanie zwłok i zastanawiał go unoszacy sie nad ciałem zapach tytoniu, przebijajacy się przez woń octu. Inspirowany swoim spostrzeżeniem, opracował metodę wykrywania nikotyny w tkankach zwłok, która pozwoliła ustalić, że Gustaw Fougnies został otruty właśnie tym alkaloidem. Sędzia śledczy, który prowadził sprawę odkrył równocześnie, że Hipolit de Bocarmé sam wytwarzał wodę kolońska z liści tytoniu. Efektem opinii, jaka wydał Jean Servais Stas, było skazanie Hippolita de Bocarmé na karę śmierci, a metoda wykrywania nikotyny znalazła zastosowanie w rozwiązywaniu spraw kryminalnych.

Pod koniec XIX wieku na brzegu Rodanu niedaleko Lyonu znaleziono kufer $\mathrm{z}$ rozkawałkowanymi zwłokami. Zwłoki nazwano zmarłym $z$ Millery. Ekspertyzę anatomopatologiczna przeprowadził Aleksander Lacassagne ${ }^{13}$, ostatecznie doprowadzając do identyfikacji zwłok, co miało istotne znaczenie $z$ punktu widzenia poszukiwań zaginionego komornika o nazwisku Gouffé. Po zbadaniu kości zwłok obliczono wzrost zmarłego $z$ Millery na $1,785 \mathrm{~cm}$, podczas gdy komornik miał 1,78 cm. Szczegółowe oględziny kości nóg zmarłego wykazały ich zmiany chorobowe. Świadkowie ze-

10 Z. Majchrzyk, Kiedy kobieta zabija, Warszawa 2009, s. 34.

11 A. Krawczuk, Neron, Warszawa 1988, s. 90.

12 J. Thorwald, Stulecie detektywów, Kraków 1992, s. 314.

13 Aleksander Lacassangge (1843-1924), francuski lekarz i kryminolog. 
znawali, że zaginiony Gouffé utykał. Analiza uzębienia zwłok dostarczyła dowodów, że zmarły był w wieku około 50 lat, podczas gdy Gouffé w chwili zaginięcia miał lat 49. Okazało się także, że włosy zwłok i włosy ze szczotki z mieszkania komornika miały takie same cechy. $\mathrm{W}$ ten sposób Aleksander Lacassagne udowodnił, że zmarly $z$ Millery to ciało komornika Gouffé. Zidentyfikowanie zwłok pozwoliło oskarżyć o zabójstwo parę: Michaela Eyrauda paryskiego sutenera i oszusta oraz Gabrielę Bombard - prostytutkę. Mężczyzna został skazany na karę śmierci, a jego wspólniczka otrzymała wyrok 20 lat ciężkich robót ${ }^{14}$.

23 kwietnia 1932 r. przed sądem we Lwowie stanęła Rita Gorgonowa ${ }^{15}$. Rita $z$ pochodzenia Dalmatynka, pracowała jako opiekunka do dzieci u architekta inż. Henryka Zaremby, którego żona przebywała w zakładzie dla psychicznie chorych. Zaremba miał córkę Elżbietę i syna Stasia. Rita związała się z Zaremba i w 1928 roku urodziła mu córkę. Dzieci Zaremby źle odbierały ten związek. 30 grudnia 1931 r. Elżbietę znaleziono martwa w willi Zaremby w Brzuchowicach. W noc jej śmierci Stasia obudził skowyt psa. Wstał z łóżka, poszedł do holu i tam między choinką a pianinem zobaczył postać kobieca. Postać przesunęła się bardzo cicho przez odchylone drzwi na werandę i znikła. Staś pomyślał, że była to Gorgonowa ${ }^{16}$. Wpadł do pokoju Lusi, zobaczył krew i zorientował się, że siostra nie żyje.

Oględziny pokoju nie wykazały żadnych śladów wskazujących na włamanie ani na podłodze, ani na częściach okna. W holu przy wejściu do pokoju Lusi znaleziono grudki kału, a nad nim na ścianie trzy plamy krwawe. Częściowo przyprószone ślady na śniegu stóp obutych w pantofle biegły od frontu do małej werandy, komunikującej $z$ sypialnią Gorgonowej, następnie rozwidlały się $\mathrm{w}$ kierunku piwniczki i basenu. W drzwiach małej werandy szyba była wybita na wysokości klamki. Ujawniono ślady krwi na murze niedaleko werandy oraz na drzwiach prowadzacych do ma-

\footnotetext{
14 G. Faix, Sûreté. Wielkie ucho Paryża, Katowice 1988.

15 [Dostęp: 12.07. 2016]. Dostępny w World Wide Web: <www.kryminalistyka. fr.pl./crime_polska_gorgonowa.php $>$.

16 S. K. Kolińska, Stynne procesy. Dramaty, tajemnice, zbrodnie, Warszawa 2008, s. 224.
} 
łej piwniczki. W piwniczce znaleziono chusteczkę z kilkoma różowymi plamkami. W basenie odkryto żelazny dżagan. Nie było na nim śladów krwi, a ogrodnik powiedział, że używał dżagana do robienia przerębli. Gorgonowa zastano w futrze i w pantoflach. Na tylnej podszewce futra były ślady kału. Pantofle były mokre $z$ dużymi rdzawymi plamami. Prawa ręka Gorgonowej była zraniona.

W pierwszym procesie R. Gorgonowa uznano za winna zabójstwa Elżbiety Zaremby i skazano na karę śmierci. Podstawowym dowodem obciążającym było rozpoznanie Rity przez Stasia Zarembę, który podobno zauważył jej postać w holu, za choinką. Po rewizji, we wrześniu 1932 r., Sąd Najwyższy wyrok uchylił i sprawa została rozpatrzona przez Sąd Okręgowy w Krakowie. Wtedy zakwestionowano wiarygodność Stasia jako świadka. 6 marca $1933 \mathrm{r}$. rozpoczą się następny proces. Zdaniem adwokata Rity ekspertyzy przedstawione w pierwszym procesie zostały wykonane niefachowo. Teraz biegły, Jan Olbrycht, stwierdził, że kał to odchody psa. Cały czas rozpatrywano problem domniemanego narzędzia zbrodni - dżagana, znalezionego na dnie basenu i braku na nim śladów krwi. Niestety, nie umiano jeszcze porównywać kształtu obrażeń, jakie powstały na czaszce $z$ konkretnym narzędziem. Kontrowersyjny był także dowód $z$ opinii po badaniu serologicznym śladów krwi na chusteczce Gorgonowej17. Sad jednak ponownie uznał Rite za winna, orzekając tym razem tylko 8 lat więzienia, przyjmujacc, że zbrodnię popełniła pod wpływem silnego wzruszenia. Ritę Gorgonowa również w drugim procesie skazano przede wszystkim na podstawie tak zwanego dowodu widmowego, stosowanego $\mathrm{w}$ czasach procesów czarownic, czyli zeznań dwunastoletniego chłopca, który widział postać Rity. Gorgonowa wyszła na wolność po 6 latach na skutek amnestii, ogłoszonej w zwiazku $z$ wybuchem wojny.

Annały kryminalistyki opisuja także długotrwały proces francuskiej wieśniaczki Marii Besnard (1896-1980)18. W roku 1949 została ona oskarżona o dwunastokrotne morderstwo na osobach swoich krewnych i znajomych. W celu rozstrzygnięcia wątpliwości

17 J. Widacki, op. cit., s. 202.

18 J. Thorwald, op. cit., s. 362. 
ekshumowano 12 zwłok i wykonano wiele analiz toksykologicznych. W 11 ciałach badania wykonane przez dra Bernarda wykazały zabójczą ilość arsenu $\mathrm{w}$ przeliczeniu na kilogram tkanek. Śmierć każdej z tych osób przynosiła Marii Besnard dziedziczenie pokaźnego spadku. W 1961 r. w trzecim procesie oskarżona uniewinniono, mimo że już $\mathrm{w}$ drugim procesie profesor P.L. Truffert zwracał uwagę, że bakterie glebowe sa w stanie przenieść arsen do zwłok. Wątpliwość, skąd się wzięła tak duża ilość arsenu $\mathrm{w}$ zwłokach, sąd uwzględnił $\mathrm{w}$ trzecim procesie, uniewinniając Marię Besnard. Ówczesny stan nauki nie potrafił rozstrzygnąć istotnej niepewności w tej sprawie.

Niewiele lat po zakończeniu wojny, w roku 1954 w Wormacji, pod zarzutem otrucia męża, teścia i przyjaciółki sądzono Christę Lehmann ${ }^{19}$. Zlecono ekspertyzę chemiczno-toksykologiczna i wtedy okazało się, że w treści żołądka wszystkich ofiar znajdują się składniki substancji określanej symbolem E 605, stosowanej w ochronie roślin. Christa Lehmann została uznana winna zarzucanych jej zabójstw i skazana na dożywotnie pozbawienie wolności. Interesujace były reperkusje tej sprawy, ponieważ do $1954 \mathrm{r}$. nigdy nie dokonano zabójstwa za pomoca E 605. Natomiast prawie natychmiast po ogłoszeniu, że za pomoca E 605 uśmiercono trzy osoby, w Niemczech i Austrii rozpoczęła się fala zabójstw oraz samobójstw $z$ użyciem tego środka. Kilku niemieckich chemików rozpoczęło walkę o szybkie opracowanie metody oznaczania zawartości E $605 \mathrm{w}$ płynach ustrojowych i tkankach osób przypadkowo zatrutych. Połowiczny sukces, który wtedy osiagnięto pozwalał ustalać zawartości E 605 we krwi.

14 stycznia 2000 r. trzy kobiety - córka, konkubina i przyjaciółka rodziny - zabiły 70-letniego Antoniego K., radcę prawnego z Chrzanowa. Najpierw próbowały go otruć pierogami $z$ nadzieniem $z$ muchomorów. Gdy to nie poskutkowało, podały mu środki usypiające w kawie. Gdy zasnał, 41-letnia Anna G., konkubina, uderzyła go łomem w głowę, a córka radcy, 43-letnia Katarzyna K., dobiła ojca, zakładajac na jego głowę torebkę foliową i przyduszając go poduszką. 41-letnia Aleksandra C. M. była ich znajoma

19 Idem, Stulecie detektywów, wyd. 2, Kraków 2009, s. 571 i n. 
i w szczegółach zaplanowała zbrodnię. Anna G., i Katarzyna K. poćwiartowały ciało, a kawałki w reklamówkach wkładały do plecaków, autobusem zawoziły do Krakowa i tam w rejonie Salwatora wrzucały je do Wisły. Jednego dnia przewiozły głowę, ręce i nogi, następnego korpus. Po dwóch tygodniach córka zgłosiła zaginięcie ojca, twierdząc, że pojechał służbowo do Warszawy. Wystapiła nawet w programie telewizyjnym, apelujacc o informacje na temat miejsca jego pobytu. Zabójstwo Antoniego K. kobiety określały między sobą kryptonimem puzzle, ponieważ łączyło się ono $z$ rozkawałkowaniem ciała ofiary. Syn radcy do poszukiwań zaangażował jasnowidza. Ten powiedział $\mathrm{mu}$, że widział las, a w nim zwłoki. Brat Katarzyny naciskał, by policja przeszukała zagajnik. Niczego jednak nie znaleziono. Trzy miesiące po zabójstwie $z$ Wisły wyłowiono korpus mężczyzny. Ale nikt nie powiązał tego ze zniknięciem radcy, ponieważ biegli stwierdzili, że chodzi o mężczyznę w wieku 40-55 lat, podczas gdy Antoni K. miał piętnaście lat więcej. Sprawę umorzono.

Cztery lata później córka - Katarzyna K. zgłosiła się do jednostki policji $z$ anonimowym listem, w którym była informacja o zwłokach wrzuconych do Wisły. Do listu był dołączony portfel i zdjęcia zaginionego radcy. Odnalezienie ciała oznaczało stwierdzenie zgonu radcy Antoniego K., realizację testamentu i przejęcie majatku. Ale policjantom $z$ krakowskiego Archiwum X wszystko wydało się podejrzane. Szybko ustalono, na jakiej maszynie list został napisany. Odkryto także, że tę maszynę kupiły występujace w sprawie kobiety oraz szybko się jej pozbyły. Szczegółowe oględziny mieszkania Antoniego K. wykazały, że w jednym z pomieszczeń zrywano parkiet. Kobiety nie potrafiły wyjaśnić powodu takiego remontu, który był jednak daremny, ponieważ w kącie pokoju ujawniono ślady krwi, które poddano badaniom DNA. W sprawie obie kobiety badano wariograficznie ${ }^{20}$. Pytanie o ukry-

20 Badania wariograficzne mają w Polsce także inna nazwę: badania poligraficzne. Niezależnie jednak od nazwy jest to instrumentalna metoda ustalania wiedzy osoby o realiach zdarzenia i modus operandi sprawcy. Definicję tę przedstawił prof. dr hab. Mariusz Kulicki dla badań wariograficznych wykonywanych na potrzeby procesu karnego. Więcej na ten temat M. Kulicki, V. KwiatkowskaWójcikiewicz, L. Stępka, Kryminalistyka. Wybrane zagadnienia teorii i praktyki śledczo-sądowej, Toruń 2009, s. 641 i n. 
cie zwłok było znaczące dla Katarzyny K. ${ }^{21} \mathrm{~W}$ kolejnym przesłuchaniu córka i konkubina radcy przyznały się do zbrodni, wskazując Aleksandrę C. M. jako kierująca zbrodnią. W lutym 2006 r. Katarzyna K. i Anna G. zostały skazane, każda na 12 lat więzienia, Aleksandra C. M., mimo że nie przyznała się do winy, ma dożywocie. Anna G. po siedmiu latach wyszła na wolność za dobre sprawowanie. Po opuszczeniu więziennych murów, korzystając z pomocy dziennikarza TVN Piotra Litki, napisała książkę opisujacca przebieg zbrodni. Choć akcja ksiażzi została przeniesiona do fikcyjnej miejscowości Brudnowo 22 , a bohaterowie maja zmienione imiona, łatwo doszukać się analogii do morderstwa radcy $z$ Chrzanowa.

24 stycznia 2012 r. wieczorem w mediach podano wiadomość o zaginięciu półrocznej dziewczynki z Sosnowca. Według relacji matki - Katarzyny Waśniewskiej (ur. 10 sierpnia 1990 r.) - podczas spaceru tajemniczy mężczyzna uderzył ją w głowę i gdy była nieprzytomna, zabrał Madzię $z$ wózka. W całej Polsce rozpoczęły się poszukiwania dziecka, które nie dały rezultatu. Matka, płacząc publicznie, prosiła porywacza, by oddał córeczkę. Ale 3 lutego 2012 r. K. Waśniewska przyznała się prywatnemu detektywowi, że porwania nie było, lecz dziecko zmarło po tym, jak w domu wypadło jej $z$ rakk. Policjanci znaleźli ciało niemowlęcia w zrujnowanym budynku w Sosnowcu. Powołano biegłych, którzy mieli odpowiedzieć na pytania: kiedy i w jaki sposób straciła życie Madzia Waśniewska?

W celu rozstrzygnięcia tej wattpliwości przeprowadzono badanie toksykologiczne i histopatologiczne wycinków narządów wewnętrznych i tkanek miękkich zmarłego dziecka. Takie badanie pozwala znaleźć zmiany na poziomie tkankowym i określić, czy śmierć osoby była przypadkowa, czy też nastapiła w wyniku celowego działania. Analiza toksykologiczna $z$ kolei jest skierowana na poszukiwanie toksycznych związów chemicznych. $Z$ ekspertyz jasno wynikało, że przyczyną śmierci dziewczynki było uduszenie. Krwiak w krtani i krew w płucach mogły powstać, jak

21 [Dostęp: 12.07.2016]. Dostępny w World Wide Web: <http://bit.ly/2gICvfP>.

22 Weronika K., Zabiłam, oprac. Piotr Litka, Kraków 2015, ss. 320. 
twierdzą biegli, tylko w wyniku uduszenia. Specjaliści nie potrafią tylko określić, czy dziecku założono worek na główkę, czy duszone było poduszka, ręką lub w inny sposób. Ciało leżało kilka dni na ostrym mrozie - po rozmrożeniu tkanki uległy uszkodzeniu. Uraz głowy, traktowany na początku jako możliwa przyczyna śmierci, powstał już po zgonie, od uderzenia główką o podłogę, ścianę, ziemię. Pobierano też próbki zabrudzeń $z$ ciała i ubranka dziecka oraz różnych miejsc, w których zwłoki Madzi mogły być ukrywane zanim umieszczono je w zrujnowanym budynku ${ }^{23}$. W wyniku badania zawartości komputera Katarzyny Waśniewskiej ustalono, że kilka dni przed rzekomym porwaniem na stronach internetowych szukano informacji o organizacji pogrzebu dziecka, cenników maleńkich trumien oraz wysokości zasiłków wypłacanych rodzicom po śmierci dziecka. Sprawdzano także, jakie sa objawy zatrucia tlenkiem węgla. We krwi Madzi biegli odkryli hemoglobinę tlenkowa, która występuje podczas zatrucia czadem. W mieszkaniu przeprowadzono oględziny pieców i przewodów kominowych, a opinia kominiarska miała odpowiedzieć na pytanie: czy były zatykane? Badania podejmowano $z$ powodu podejrzenia, że Katarzyna Waśniewska próbowała zabić córkę co najmniej od 19 stycznia 2012 r., usiłujacc zatruć ją czadem, uderzając dzieckiem o podłogę, a nawet podduszając niemowle przez kilka minut. W tej sytuacji 31 grudnia 2012 r. Prokuratura Okręgowa w Katowicach skierowała do sądu akt oskarżenia przeciwko K. Waśniewskiej z zarzutem zabójstwa Madzi. 3 września 2013 r. Sąd Okręgowy w Katowicach wymierzył Katarzynie Waśniewskiej (Rycina 8) karę 25 lat więzienia za zabicie córki oraz za zawiadomienie o niepopełnionym przestępstwie, odrzucając wersję obrony, że Magda zmarła na skutek wypadku.

Obrońca złożył apelację, żądając wykonania uzupełniających badań, m.in. przez biegłego laryngologa dziecięcego. Według obrony śmierć Madzi była spowodowana laryngospazmem, czyli nagłym skurczem krtani. Biegli analizowali dokumentację $z$ sekcji zwłok dziecka i badań lekarskich przeprowadzonych za jego życia. Zgodnie stwierdzono, że co prawda historia medycyny zna przy-

23 [Dostęp: 30.07.2016]. Dostępny w World Wide Web: <http://bit.ly/2fAz8pn>. 
padki, w których laryngospazm był śmiertelny, jednak są one niezmiernie rzadkie i dotycza powikłań po znieczuleniu, które w tym przypadku nie wystapiło. Opinia biegłych była jednoznaczna: półroczna Magda zmarła wskutek gwałtownego uduszenia. Przyczyna śmierci nie była choroba ani uraz. Kobieta została skazana prawomocnym wyrokiem na 25 lat pozbawienia wolności za zabicie swojej sześciomiesięcznej córki Magdy.

Wiele kobiet, nie tylko te w opisanych wyżej przypadkach sadzonych za zabójstwo, zapisało swoja historię na kartach kryminalistyki. Opinie biegłego miały w ich procesach różne znaczenie. W przypadku procesu oskarżonej o zabójstwo męża Marii Capelle Lafarge w roku 1840, po raz pierwszy w naukowy sposób dowiedziono użycia arszeniku do pozbawienia życia ${ }^{24}$, co skutkowało skazaniem Marii. Z kolei sadzona w 1856 r. Madeleine Smith ${ }^{25}$ najprawdopodobniej zabiła kochanka, który jej przeszkadzał, ale została uniewinniona, bo nie umiano usunać watpliwości dotyczących sposobu i czasu podania trucizny. Janinę Borowską w 1910 r. uwolniono od zarzutu zabójstwa adwokata Włodzimierza Lewickiego, chociaż do ustalenia przebiegu zdarzenia zastosowano niezwyczajny ówcześnie eksperyment. Powołano w tym celu dwóch znawców broni - oficera armii i rusznikarza, którzy strzelali do manekina ustawianego w różnych pozycjach i różnych miejscach pokoju. Ostatecznie jednak wątpliwości pozostały i biegli uznali, że mogło to być bardzo typowe samobójstwo, lub bardzo nietypowe morderstwo 26 .

Eva Rablen ${ }^{27}$, skazana w 1929 r. za zabójstwo męża, nie przewidziała, jakie konsekwencje może przynieść kawa rozlana przypadkiem na sukienkę koleżanki. Przenikliwy śledczy zlecił ekspertyzę plamy i wtedy wykryto, że płyn zawierał także strychninę. $Z$ kolei Lindy Chamberlain, oskarżona o to, że w 1980 r. zabiła córeczkę, musiała latami dowodzić swojej niewinności, po-

24 Dowodów przeciwko Marii Capelle Lafarge dostarczyły badania pioniera toksykologii Mateusza Bonawentury Josepha Orfili. B. Innes, Niezbity dowód. Metody wykrywania zbrodni, Warszawa 2001, s. 48.

25 F. McLynn, Słynne procesy. Sprawy, które tworzyły historię, Warszawa 1996, s. $122 \mathrm{i} \mathrm{n.}$

26 J. Widacki, op. cit., s. 154.

27 [Dostęp: 12.07.2016]. Dostępny w World Wide Web: <http://bit.ly/2gIDFYq>. 
nieważ australijski wymiar sprawiedliwości, mimo licznych opinii biegłych nie mógł uwierzyć, że dziecko mógł porwać i zabić dziki pies dingo.

Opinia biegłego ma istotne znaczenie w ustalaniu okoliczności zdarzenia. Pozwala wskazać rodzaj zdarzenia (przestępstwo, samobójstwo, nieszczęśliwy wypadek), biegły może też określić miejsce zdarzenia oraz jego czas. Badania daja możliwość poznania sposobu działania sprawcy oraz rodzaju narzędzia, które zastosowano do realizacji przestępczego działania. Zaznaczyć jednak należy, że opinia biegłego zawsze miała znaczenie adekwatne do stanu nauki w danym okresie historycznym. Wraz z rozwojem nauki rosły możliwości badawcze biegłego, ustalanie okoliczności zdarzenia pozwalało rozstrzygać więcej watpliwości. W słynnych procesach przeciwko kobietom opinie biegłych:

- czasem, nie potrafily rozstrzygnąc wątpliwości i dawały uniewinnienie oskarżonym, jak $\mathrm{w}$ postępowaniach przeciwko Janinie Borowskiej i Marii Besnard,

- czasem były mylne i dopiero zbieg okoliczności decydował o ustaleniu sprawcy, jak wtedy, gdy córka $z$ koleżankami zabiła ojca,

- czasem prowadziły do obarczenia wina jednej osoby i uniewinnienia drugiej, jak w przypadku Lidii de Bocarmé,

- czasem nie były brane pod uwage, co skutkowało surowym wyrokiem, jak w sprawie Rity Gorgonowej,

- najczęściej jednak dawały możliwość wymierzenia kary, co przedstawiaja procesy Gabrieli Bombard, Christy Lehmann i Katarzyny Waśniewskiej.

\section{Bibliografia}

\section{Autobiografia}

Weronika K., Zabiłam, oprac. Piotr Litka, Kraków: Wydawnictwo WAM, 2015, ISBN 978-83-277-1061-1. 


\section{Zasoby internetowe}

[Dostęp: 12.07.2016]. Dostępny w World Wide Web: <http://bit.ly/2gICvfP>. [Dostęp: 12.07.2016]. Dostępny w World Wide Web: <http://bit.ly/2fABIfe>. [Dostęp: 30.07.2016]. Dostępny w World Wide Web: <http://bit.ly/ 2fAxNPp>.

[Dostęp: 12.07.2016]. Dostępny w World Wide Web: <http://bit.ly/ 2 fxzycE $>$.

[Dostęp: 12.07.2016]. Dostępny w World Wide Web: <http://bit.ly/ 2gIDFYq $>$.

[Dostęp: 30.07.2016]. Dostępny w World Wide Web: <http://bit.ly/ 2fAz8pn>.

[Dostęp: 1.08.2016]. Dostępny w World Wide Web: <http://bit.ly/2gqTend>.

\section{Opracowania}

Alexander D., Czarownice, wróżbici, szamani. Podróż przez świat mitów i magii, Warszawa: Świat Książki, 2008, ISBN 978-83-247-0556-6.

Bonda K., Lach B., Zbrodnia niedoskonała, Katowice: Videograf II, 2009, ISBN 978-83-7183-671-8.

Bonda K., Polskie morderczynie, Warszawa: Muza, 2008, ISBN 978-837495-519-5.

Faix G., Sûreté, Wielkie ucho Paryża, Katowice: Wydawnictwo Śląsk, 1988, ISBN 83-216-0694-6.

Innes B., Niezbity dowód: metody wykrywania zbrodni, Warszawa: Muza, 2001, ISBN 83-7319-010-4.

Kędzierski W., Ekspertyza. Biegli [w:] Kryminalistyka. Wybrane zagadnienia techniki, red. G. Kędzierska i W. Kędzierski, Szczytno: Wydawnictwo Wyższej Szkoły Policji, 2011, ISBN 9788374622677.

Kolińska S. K., Stynne procesy. Dramaty, tajemnice, zbrodnie, Warszawa: Świat Książki, 2008, ISBN 978-83-247-0820-8.

Krawczuk A., Neron, Wyd. 5, Warszawa: Czytelnik, 1988, ISBN 83-0701754-8.

Kulicki M., Kwiatkowska-Wójcikiewicz V., Stępka L., Kryminalistyka: wybrane zagadnienia teorii i praktyki śledczo-sadowej, Toruń: Wydawnictwo Naukowe Uniwersytetu Mikołaja Kopernika, 2009, ISBN 978-83-231-2401-6.

Majchrzyk Z., Kiedy kobieta zabija: motywy, osobowość, relacja sprawca-ofiara, strategie obronne: opinia sadowo-psychologiczna stanu silnego wzburzenia, Warszawa: Wydawnictwo Uniwersytetu Kardynała Stefana Wyszyńskiego, 2009, ISBN 978-83-7072-578-5. 
McLynn F., Słynne procesy: Sprawy, które tworzyły historie, Warszawa: Dertor, 1996, ISBN 83-901765-1-3.

Murzynowski A., Istota i zasady procesu karnego, Wyd. 3, Warszawa: Wydawnictwo Naukowe PWN, 1994, ISBN 83-01-11585-8.

Szenic S., Pitaval wielkopolski, Wyd. 2, Poznań: Wydaw. Poznańskie, 1977.

Thorwald J., Stulecie detektywów: drogi i przygody kryminalistyki, przeł.

Wanda Kragen i Karol Bunsch, Kraków: Wydawnictwo Literackie, 1992, ISBN 83-08-02175-1.

Thorwald J., Stulecie detektywów: drogi i przygody kryminalistyki, przeł.

Wanda Kragen i Karol Bunsch, Kraków: Wydawnictwo Znak, 2009, ISBN 978-83-240-1118-6.

Widacki J., Stulecie polskich detektywów, Kraków: Wydawnictwo Wawelskie, 1992, ISBN 83-85347-04-6.

Wrzesiński S., Potepieńcy średniowiecznej Europy, Kraków: Wydawnictwo EGIS, 2007, ISBN 978-83-7396-627-7. 